\title{
ACRL programs at the 2016 ALA Annual Conference
}

\section{A brief overview}

\section{ACRL Board of Directors}

- Board of Directors Meeting I: Saturday, June 25, 1:30-5:30 p.m.

- Board of Directors Meeting II: Monday, June 27, 1:30-4:30 p.m.

During Board I, there will be an open microphone period from 4:00-4:30 p.m. Please note that this period cannot be used to request that the Board take an immediate action. All guests planning to address the Board during the open microphone session are asked to arrive by 4:00 p.m.

\section{Sessions highlights}

Saturday, June 25, 2016

Lessons from IMLS Funded Communities of Practice, 1:00-2:30 p.m. Learn about Communities of Practice (CoPs), a concept coined by Jean Lave and Etienne Wenger. Representatives from IMLS, ACRL's Assessment in Action, YOUMedia Learning Labs, STAR_NET, and other national and state-based CoPs, will share new perspectives about CoPs to inform both research and practice about learning and effective facilitation of library-based and online learning in and through CoPs. The goals of the forum are to: 1 ) build capacity for creating CoPs, 2) identify new synergies resulting from exploring lessons learned from a variety of CoPs, and 3) foster promising, equitable, and engaging design work around the idea of communities of practice.

SPARC-ACRL Forum, 3:00-4:30 p.m. Through its standing Research and Scholarly Environment Committee, ACRL sponsors a regular forum at both the ALA Midwinter Meeting and ALA Annual Conference to broaden the base of librarians who are knowledgeable about and engaged in scholarly communication issues. The highly popular forum series is cosponsored by the Scholarly

\section{Annual Conference information online}

Find complete details on ACRL programs in Orlando on the ACRL at Annual Conference web page. Go to www.ala.org/acrl, select Conferences \& Events," and click on "ACRL 2016 Annual Conference Presentations" for the latest details.

Locations for programs and a complete listing of ACRL meetings, along with discussion group and interest group information, will be available in the Annual Conference Scheduler. Fully registered attendees can create a personalized agenda and search for meetings, programs, and event times and locations.

The Annual Conference Scheduler will be available on the conference website at http://2016.alaannual.org/. 


\section{ACRL President's Program/Preconferences}

ACRL President's Program, Saturday, June 25, 2016, 10:30 a.m.-12:00 p.m. Strategies and Partnerships: Tailoring Data Services for Your Institutional Needs. In nearly every discipline, understanding how to find and use data effectively and how to create and manage your own data for re-use are emerging critical competencies in higher education.Approaching data services at the institutional level requires coordinated communication and collaboration across units and/or externally.The speakers will address multiple approaches for academic libraries of various sizes to tailor their engagement with data services to their institutional priorities. Speakers: Sara Bowman, project manager, Center for Open Science; Yasmeen Shorish, scholarly communication and data ser-

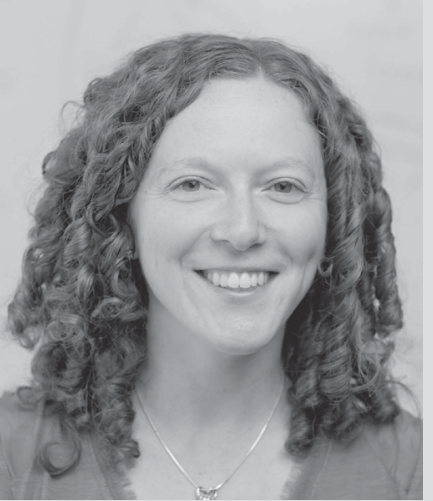

Sara Bowman eracy. This half-day, hands-on workshop will build librarians' capacity as leaders on issues and projects of campuswide interest that involve elements of scholarly communication, information literacy, and their connections (i.e., data literacy, intellectual property, open access, etc.).

Friday, June 24, 2016. Crossing the Threshold with Threshold Concepts: Redesigning a Library Instruction Lesson Plan. The Framework for Information Literacy for Higher Education offers a more conceptual approach to information literacy instruction by providing a set of "interconnected core concepts" rather than standards. In this full-day preconference, participants will learn, and put into practice strategies, to incorporate these threshold concepts into lesson design.

Friday, June 24, 2016. Teaching Data Information Literacy: A Hands-on Introduction. This interactive preconference, presented by the ACRL Instruction Section, consists of two parts. First, presenters will share their experiences in developing instruction around data information literacy. Part two will be conducted through handson exercises, in which participants will have the opportunity to formulate what they see as the most important skills for their target audience to acquire. 
Publishing and Academic Resources Coalition (SPARC). The topic and speakers are chosen 60 to 90 days before the conference, based on issues that are most relevant at that time.

\section{Sunday, June 26, 2016}

Update on the ACRL Framework for Information Literacy for Higher Education, 10:30-11:30 a.m. Hear the latest news about the Framework for Information Literacy for Higher Education, including the launch of the Framework "sandbox" for examples and experimentation by the community. Learn about ACRL's professional development resources designed to assist librarians in using the Framework and contributing to its growth.

\section{Update on Value of Academic Libraries} Initiative (ACRL), 1:00-2:30 p.m. Learn about the range of activities being undertaken by ACRL as part of its VAL initiative.

\section{ACRL special events at 2016 ALA Annual Conference}

Friday, June 24

College Libraries Section. Friday Night Feast, Bravo! Pre-registration required, 5:30-7:30 p.m. Contact: Alicia Hansen, ahansen@holycross.edu.

\section{Education and Behavioral Sciences Sec-}

tion. Social, Taverna Opa, no registration required, 7:00 p.m. Contact: Elena Soltau, soltau@nova.edu.

\section{Anthropology and Sociology Section.}

Dinner, Lowe's Royal Pacific Resort, Islands Dining Room, RSVP requested, 7:30 p.m. Contacts: Wade Kotter, wkotter@weber.edu, and Jill Conte, jill.conte@nyu.edu.

Saturday, June 25

Instruction Section. Soiree, Orlando Hilton, David's Club Bar \& Grill, no regis- tration required, 5:30-7:30 p.m. Contacts: Tammera Race, trace@ncf.edu and Leecy Barnett,lbarnett@lynn.edu.

\section{Library Marketing and Outreach Interest}

Group. Social, Marlow's Tavern, no registration is required, 5:30 p.m. Contact: Amy Wainwright, awainwright@jcu.edu.

Literatures in English Section. Social, Café $\mathrm{Tu} \mathrm{Tu}$ Tango, no registration is required, 5:30-7:00 p.m. Contact: Liorah Golomb, lgolomb@ou.edu.

University Libraries Section. Social, Taverna Opa, no registration required, 5:30-7:00 p.m. Contacts: Leslie Sult, 1sult@email.arizona. edu, and Sara Holder, sara.holder@mcgill.ca.

\section{Sunday, June 26}

Law and Political Science Section. Marta Lange/SAGE-CQ Press Award Breakfast, preregistration required, 8:30-10:00 a.m. Contact: Mary Kathryn Oberlies, moberlie@gmu.edu.

Distance Learning Section. Award Luncheon, pre-registration required, 11:30 a.m.-1 p.m. Contacts: Rebecca Nowicki, Rebecca. nowicki@ashford.edu, and Brandon West, westb@geneseo.edu.

\section{Community \& Junior College Libraries Sec-} tion. Awards and dinner meeting, Cuba Libre, pre-registration is required, 6:00-9:00 p.m. Contact: Julia Mielish, julia.mielish@gmail.com.

Science and Technology Section. Dinner, Café Tu-Tu Tango, pre-registration is required, 6:00-8:00 p.m. Contact: Beth BlantonKent, bwb9f@eservices.virginia.edu.

Western European Studies Section. Reception, Cuba Libre, pre-registration is required, 7:00-9:00 p.m. Contact: Adan Griego, griego@ stanford.edu. $\boldsymbol{n}$ 


\section{ACRL Discussion Groups}

Assessment: Saturday, June 25, 3:00-4:30 p.m. Topic: The ACRL Assessment Discussion Group provides an informal forum for sharing ideas and best practices in library assessment, as well as an opportunity for professional networking.

Balancing Baby and Book: Sunday,June 26, 4:30-5:30 p.m. Topic: The Balancing Baby and Book Discussion Group is a fun and informal group that includes all types of librariansmoms,dads,new parents, potential parents, and anyone else interested in how parenting and librarianship can be successfully intertwined. HR issues, daycare, tenure, and a variety of other topics can be discussed. Everyone is welcome.

Continuing Education/Professional Development: Saturday, June 25, 1:00-2:30 p.m. Topic: Responding to change. Come together to discuss strategies to support development of skills and knowledge needed in an ever-evolving library environment.

Copyright: :Saturday,June 25, 10:30-11:30 a.m. Topic: The ACRL Copyright Discussion Group reviews and discusses legislative, judicial, and regulatory developments related to copyright (and licensing) in libraries of tertiary educational institutions.

First Year Experience: Saturday, June 25, 8:30-10:00 a.m. Topic: Annual meeting of the ACRL First Year Experience Discussion Group.

Heads of Public Services: Saturday, June 25,4:30-5:30 p.m. Topic: Discussion of issues related to staffing, space allocations and reorganizations, embedded/liaison librarianship, and other current topics that may emerge as we gather.

Information Commons: Saturday, June 25, 1:00-2:30 p.m. Topic: New Services and Partnerships in the Information Commons. What are you planning, and how are you deciding on scope and fit for adding new services and partners at your IC?

Leadership: Saturday, June 25, 3:00-4:00 p.m. Topic: Leadership roles in the academic library.
Library and Information Science Collections: Sunday, June 26, 8:30-10:00 a.m. Topic: What library science materials do you use in your day-to-day professional life? Even if you aren't a liaison librarian to a library science school, college, or program, come prepared to talk about those library science-related materials that are indispensable to your career in librarianship.

MLA International Bibliography in Academic Libraries: Saturday, June 25, 10:30-11:30 a.m. Topic: The Modern Language Association International Bibliography.

Media Resources: Sunday,June 26, 10:3011:30 a.m. Topic: Accessibility Issues for Video Resources. General discussion (not a presentation or a product demonstration) on accessibility as it relates to video, both created in house and obtained from outside sources-come talk about the issues, problems, and requirements librarians are facing.

New Members:Virtual.Topic:Staff,Students, and Student Staff:Supporting Diversity throughout Academic Libraries.

Personnel Administrators \& Staff Development: Saturday,June 25, and Sunday,June 26, 10:30-11:30 a.m. Topic:A discussion of topical issues, emerging trends, and best practices by personnel and staff development officers.

Philosophical, Religious, and Theological Studies: Sunday,June 26,4:30-5:30 p.m. Topic: PhilPapers or Philosopher's Index? What to do when you can't afford both. Presentation and discussion.

Scholarly Communication: Sunday,June 26,3:00-4:00 p.m. Topic: Economic Models for Transitioning Journals to Open Access.

Undergraduate Librarians: Sunday, June 26, 10:30-11:30 a.m. Topic: Join in and share your ideas, approaches, success stories, and lessons learned about serving undergraduate populations. Previous topics have included events to increase library engagement, effective campus partnerships, strategic timing for outreach efforts, interactions with student groups, and more. 